Etnográfica

Revista do Centro em Rede de Investigação em

Antropologia

vol. $16(2) \mid 2012$

Vol. $16(2)$

\title{
O divino retorno: uma abordagem fenomenológica de fluxos identitários entre a religião e a cultura
}

The holy return: a phenomenological approach of identity flows between religion and culture

José Rogério Lopes

\section{CpenEdition}

Journals

Edição electrónica

URL: https://journals.openedition.org/etnografica/1526

DOI: 10.4000/etnografica.1526

ISSN: 2182-2891

Editora

Centro em Rede de Investigação em Antropologia

Edição impressa

Data de publição: 1 junho 2012

Paginação: 339-364

ISSN: 0873-6561

Refêrencia eletrónica

José Rogério Lopes, «O divino retorno: uma abordagem fenomenológica de fluxos identitários entre a religião e a cultura», Etnográfica [Online], vol. 16 (2) | 2012, posto online no dia 26 junho 2012, consultado o 12 fevereiro 2022. URL: http://journals.openedition.org/etnografica/1526 ; DOI: https:// doi.org/10.4000/etnografica.1526

\section{(c) (;) (9)}

Etnográfica is licensed under a Creative Commons Attribution-NonCommercial 4.0 International License. 


\section{O divino retorno: uma abordagem fenomenológica de fluxos identitários entre a religião e a cultura}

\section{José Rogério Lopes}

$\mathrm{O}$ artigo analisa algumas transformações ocorridas na tradicional Festa do Divino Espírito Santo, realizada na cidade de São Luiz do Paraitinga, estado de São Paulo, Brasil. Em janeiro de 2010, uma enchente atingiu a cidade, derrubando parte de seu patrimônio cultural. Essa perda baixou a autoestima da população e vários agenciamentos religiosos e de políticas culturais emergiram no processo de recuperação da cidade. Através de uma abordagem fenomenológica, busca-se descrever e analisar a dinâmica desses agenciamentos na realização da Festa do Divino desse ano, evidenciando os fluxos identitários que atravessam os campos da religião e da cultura, buscando se sobrepor na produção do evento.

PALAVRAS-CHAVE: patrimônio cultural, religiosidade, agenciamentos identitários, fluxos.

The holy return: a phenomenological approach of identity flows between religion and culture - The article analyzes some transformations in the traditional Festival of the Holy Spirit held in São Luiz do Paraitinga, a small town in the state of São Paulo, Brazil. In January 2010, a violent flood destroyed part of its built cultural heritage. That loss lowered the population's self-esteem and many religious and cultural-policy agencies emerged in the process of recovery. Through a phenomenological approach, the article describes and analyzes the dynamics of such agencies in that year's Festival of the Holy Spirit, showing the identity flows that cut across the fields of religion and culture, and their overlapping in the production of the event.

KEYWORDS: cultural heritage, religiosity, identity agencies, flows.

LOPES, José Rogério (jrlopes@unisinos.br) - Universidade do Vale do Rio dos Sinos (Unisinos), RS, Brasil 


\section{A FESTA DO DIVINO ESPÍRITO SANTO E AS MUDANÇAS NO ESPÍRITO DA FESTA DO DIVINO}

A Festa do Divino tem uma tradição de mais de 200 anos em São Luiz do Paraitinga, uma pequena cidade localizada no alto da serra do Mar, região leste do estado de São Paulo, Brasil. Nesse período, a festa vem sendo realizada regularmente, com um intervalo de exceção entre 1918 e 1939 (J. Almeida 2001). ${ }^{1}$ Essa "antiguidade", sempre enfatizada pelas pessoas do lugar, carrega marcas identitárias profundamente relacionadas à região, que já foi uma das maiores produtoras de café do país, durante o século XIX, e à cidade, que preservou dezenas de casarões imperiais e algumas igrejas do período. ${ }^{2}$ A importância dessas edificações, algumas projetadas por Euclides da Cunha, fez a cidade ser tombada pelo Condephaat ${ }^{3}$ como patrimônio histórico ${ }^{4}$ estadual, em 1982. Alia-se a essa antiguidade inscrita nos casarões, igrejas e festas, o fato de a cidade estar incrustada no "mar de morros" que caracteriza a topografia desse trecho da serra do Mar, entre o vale do rio Paraíba e o litoral norte do estado de São Paulo. Dessa forma, o entorno da cidade é rico de paisagens naturais, destacando-se a floresta remanescente de mata atlântica que hoje está protegida pelo Parque Estadual da Serra do Mar, criado em 1977.

A localização da cidade, relativamente isolada dos fluxos de modernização ${ }^{5}$ que se desenvolveram nas margens da rodovia Presidente Dutra, durante o

I Agradecimentos ao CNPq e à Capes, pelo auxílio financeiro que subsidiou a pesquisa cujos dados são em parte considerados aqui, e aos colegas do Núcleo de Estudos da Religião (NER), da UFRGS, pelas contribuições na discussão desse artigo.

2 Destacam-se três igrejas na paisagem da cidade: a igreja Matriz de São Luiz de Tolosa, na praça Oswaldo Cruz, teve duas construções, a primeira - pela comunidade - no início do século XIX, e a segunda, erigida pela elite agrária local, entre 1839 e 1900; a capela das Mercês, localizada na rua Coronel Domingues de Castro, data do início do século XIX e foi erigida por uma devota local; a igreja do Rosário, construção em estilo neogótico, localizada em um morro mais elevado que as demais, datada de 1921 e erigida pela Irmandade de São Benedito, com recursos comunitários (Toledo 2001; J. Almeida 1987).

3 Conselho para o Desenvolvimento do Patrimônio Histórico, Arquitetônico e Artístico do Estado de São Paulo.

4 A concepção de patrimônio histórico, ou histórico-arquitetônico, explicita um modelo de "colecionamento de objetos materiais, cujo efeito é demarcar um domínio subjetivo em oposição a um determinado 'outro' [...] com o propósito de acumular e reter bens que são reunidos" (Gonçalves 2003: 22). Geralmente, tal concepção firma-se como categoria preservacionista (paradoxalmente moderna), com delimitações relacionadas com a de propriedade. Todavia, pretende-se mostrar que os acontecimentos aqui descritos levam a pensar sobre os limites e possibilidades de compreensão da vida social e cultural que a concepção de patrimônio provoca.

5 A ideia de uma cidade isolada dos fluxos de modernização, na sociedade contemporânea, pode parecer paradoxal. Contudo, a referência a modos de modernização que operam por fluxos segue a concepção de Williams (1974), de que os fluxos não têm sequência. Assim, mesmo situada próximo da rodovia que liga os dois maiores pólos de desenvolvimento do país (São Paulo e Rio de Janeiro), e "integrada com os meios mais modernos de comunicação existentes em nosso país - [continua] 
século XX, permitiu a manutenção de seus traços tradicionais, configurados em um ambiente cultural de expressiva formação caipira, segundo Brandão (1983, 1995), ${ }^{6}$ onde a presença irregular de missionários católicos, até o fim do período imperial, influenciou a difusão de uma "cultura bíblico-católica" (Brandão 1986) que se manifesta na crescente exteriorização da fé, em modelos devocionais diversos. Um desses modelos, segundo Hoornaert (1983), se organizou em torno da devoção e das festividades ao Divino Espírito Santo. ${ }^{7}$

Apesar da percepção valorativa inscrita na "conaturalidade entre o tema do Espírito Santo e a religião popular”, para esse autor, importa aqui destacar que a Festa do Divino, em São Luiz do Paraitinga como em outras localidades (Leal 1994; Abreu 1999; Jurkevics 2005; Peixoto e Neto 2006; Ferretti 2007; Santos 2008), sempre foi organizada em um campo de tensões entre a população local e as representações eclesiásticas, oscilando em referências hierárquicas ora mais, ora menos controladas pelas últimas.

Outro aspecto a aproximar analiticamente as festividades ao Espírito Santo está em que a importância do evento assenta-se na sustentação de uma rede de relações entre pessoas, grupos familiares e bairros rurais da região. Essa rede facilita agenciamentos de recursos sociais diversos, para além da esfera religiosa (Gonçalves 2002; Perez 2000; M. Silva 2000; Leal 1994; Brandão 1978), e ultrapassa em muito os limites do município, estendendo-se para os municípios vizinhos e, daí, até o vale do Paraíba e o litoral norte do estado de São Paulo. Boa parte dessas relações se reforça, durante todo o ano, pela peregrinação da Folia do Divino. ${ }^{8}$

como a Internet, TV a cabo -, é inegável o quanto ainda impera um modo de vida singular em localidades como São Luiz do Paraitinga, em uma posição totalmente diferente daquela pregada como moderna pelos grandes centros" (Santos 2008: 3).

6 Essa formação caipira é tão evidente, ainda hoje, em vários traços constitutivos da vida coletiva, na cidade e em sua zona rural, que alguns atores culturais locais estão organizando um dossiê para solicitar o tombamento dessa cultura imaterial, junto ao Instituto do Patrimônio Histórico e Artístico Nacional (IPHAN). O interessante dessa iniciativa é que ela surgiu como estratégia de enfrentamento ao plantio extensivo de eucalipto que a empresa VCP - Votorantin Celulose e Papel promove no município, desde final da década de 1990.

7 Segundo Hoornaert (1983), a devoção ao Espírito Santo escapava ao controle da Igreja, no período colonial, devido ao seu caráter inspirador, emocionante e animador, que "se comunica através de uma experiência de vida e não tanto através da palavra". As diversas e grandiosas festas ao Divino Espírito Santo que surgem nos períodos colonial e imperial ganharam tanta aceitação que algumas permanecem grandiosas até hoje. "O tema do Espírito Santo fugiu à manipulação pelo poder dominante e emergiu com as manifestações sempre mais evidentes da religião popular em tempos recentes. A rápida aceitação - por parte do povo - da experiência extática cultivada em cultos sobretudo pentecostais demonstra que sempre houve uma conaturalidade entre o tema do Espírito Santo e a religião popular: o Espírito Santo se 'manifesta' pela expressão corporal, meio de comunicação próprio dos oprimidos aos quais a expressão verbal está sendo negada” (Hoornaert 1983: 346).

8 Trata-se de um grupo votivo de devoção ao Divino Espírito Santo, com formação semelhante às Folias de Santos Reis e mantido pela coordenação da festa de cada ano, que "esmola" por toda a região, pousando em lugares e períodos específicos durante sua peregrinação. A cada pouso, [continua] 
O evento tem duração de duas semanas, realizando-se no período das celebrações de Pentecostes ${ }^{9}$ - datação que oscila no calendário litúrgico das celebrações oficiais da Igreja Católica - e é composto de uma diversidade de atividades. A primeira delas é a procissão das bandeiras, ocorrida na primeira sexta-feira da festa. Nesse cortejo, o pároco local abençoa a bandeira do casal de festeiros do ano, que é nova, e inaugura o Império do Divino. ${ }^{10}$ No sábado, ocorre o Encontro das Bandeiras, um cortejo que se inicia na casa dos festeiros e segue até a praça Teodoro Coelho, em frente ao hospital, onde antigos festeiros, juntamente com o casal de festeiros do ano, reúnem suas bandeiras particulares e dali seguem até o Império, onde a bandeira do ano fica em exposição. No domingo, ocorrem duas missas na igreja Matriz e, ao final da tarde, são coroados o rei e a rainha da festa (reis congos), figuras simbólicas que participam dos principais rituais processionais. Depois, há um novo cortejo com esses atores, o pároco, membros de irmandades locais e a banda de música da cidade segue até o Império do Divino, onde se encerra. Segue-se uma semana de rogação de ladainhas, pelas manhãs, e novenas diárias, às noites.

O segundo sábado da festa amanhece com alvorada de rojões, seguida pela distribuição do afogado à população, no almoço. À tarde, ocorre uma apresentação da cavalhada, um auto de cavalaria que dramatiza a vitória de Carlos Magno sobre os mouros. Na praça Oswaldo Cruz, durante a mesma tarde, bonecos gigantes saem para brincar com as crianças do lugar. Nesse dia, não há missa na programação oficial, evidenciando um tempo de exceção, profano, em meio das celebrações.

[continuação] a Folia atrai centenas de pessoas, que reproduzem o espírito da festa em comemorações locais, fazendo doações diversas, em espécie ou dinheiro, que serão revertidas para a Festa do Divino, em geral na distribuição do afogado - cozido de carnes e batata servido no almoço do sábado final da festa - ou de café com paçoca que é servido à população e seus visitantes, durante o período. Estudos detalhados dessa manifestação estão elaborados nas obras de Veiga (2008), Jaime de Almeida (2001, 1987) e de Brandão (1981, 1978). Para análise de manifestações correlatas, no ciclo devocional do Divino Espírito Santo, ver Ferretti (2007), M. Silva (2000), Leal (1994).

9 "No Velho Testamento, Pentecostes era a festa judaica de colheita do trigo (Chawuot), celebrando sua maturação e colheita sete domingos ou cinquenta dias após a Páscoa, com oferendas e sacrifícios. $\mathrm{Na}$ história bíblica, foi num domingo de Pentecostes que a Virgem Maria e os doze apóstolos de Cristo receberam o Espírito Santo sob a forma de 'línguas de fogo' e, falando em numerosas línguas, dispersaram sua fé pelo mundo. Para os cristãos, esse é o marco de fundação da Igreja Católica e de sua diáspora evangelizadora pelo mundo" (Veiga 2008: 136).

10 Império é o nome dado aos locais de guarda e exposição pública dos santos padroeiros das festas, na região. Em geral, esse nome é mais utilizado nas festas dedicadas ao Divino Espírito Santo e originalmente designava a própria festa (Abreu 1999), mas já constatei seu uso para designar os locais de guarda de outros santos, em festas locais. Nesse recinto, ricamente decorado em tons de vermelho e dourado, fica exposta também a bandeira da festa do ano. Ali, os devotos podem fazer visitação, rezar, pagar promessas, além de se receberem santinhos da festa ou um saquinho com "sal do Divino", que se acredita ser abençoado e portador de saúde quando utilizado nos alimentos. 
Nos intervalos dessas atividades, a praça e as ruas da cidade, até o mercado municipal, costumam ficar lotadas de pessoas circulando, entre encontros familiares e de amigos para comer, beber e conversar, ou para assistir as apresentações dos grupos devocionais de moçambiques, congadas e folias de reis, tanto os da cidade quanto os grupos convidados de outros locais.

O domingo também amanhece com alvorada de rojões, mas a sequência de rituais e atividades que se desenrola na cidade é bem mais intensa. São três manifestações importantes: o cortejo do Divino, às 10 horas, que traslada o andor do Divino do Império até a igreja Matriz, onde se realiza uma missa; a procissão do Mastro, às 12 horas, que traslada um mastro com a bandeira do Divino, da igreja Matriz até o adro da igreja do Rosário, onde o mesmo é fincado; a procissão do Divino, às 18 horas, que sai da igreja Matriz com o andor do Divino e de alguns santos patronos de irmandades da cidade, percorrendo as principais ruas do centro histórico da cidade, até retornar para a mesma igreja, onde se realiza a missa de encerramento da festa, com o anúncio dos festeiros do próximo ano. Essas manifestações centrais produzem uma gradual efervescência nos circuitos festivo-religiosos realizados no dia e condicionam os outros circuitos secundários do evento, religiosos ou seculares, em suas dinâmicas. ${ }^{11}$ Um deles é o relacionado às apresentações dos grupos devocionais já citados. São dezenas deles, cantando e tocando seus instrumentos em cadências e ritmos os mais diversos, pelos lugares centrais da festa: em frente ao Império (parada inicial obrigatória para todos) ou à igreja Matriz, na praça Oswaldo Cruz, no mercado (ocasionalmente), nas ruas do centro histórico e durante os cortejos e as procissões.

O ambiente audiovisual da festa proporcionado por essas atividades é acrescido de uma rica decoração, por todo o centro histórico e arredores da cidade, que inclui cordões de bandeirinhas coloridas espalhadas dos coretos das praças até os postes e pelas ruas, além de bandeirolas e flâmulas vermelhas enfeitando as janelas dos casarões e das casas, faixas e adereços nos postes, com iconografias do Divino Espírito Santo.

Esse retrato sucinto da festa ${ }^{12}$ caracteriza um modelo que predominou durante décadas, no século XX, oscilando pouco em sua organização e

11 Nesse período, em recantos mais afastados do centro histórico, é possível presenciar a realização de danças de jongo e lundu, inclusive, como algumas que presenciei entre 1986 e 1992.

12 Enfatizo que esse esboço do evento não tem pretensão de se assumir como etnografia, mas, sim, de evidenciar a correlação entre as manifestações que o compõem e os lugares patrimonializados da cidade, configurados em circuitos. Nesse sentido, denomino como circuito um trajeto específico demarcado pela movimentação de atores significativos na produção de um evento festivo. No caso em análise, os circuitos que demarcam os cortejos processionais ocorridos na festa estão relacionados aos eventos originais que compõem o imaginário devocional ao Divino Espírito Santo e seus desdobramentos históricos. A esse respeito, ver Abreu (1999), Gonçalves (2002), Santos (2008), Carvalho (2008). 
programação. ${ }^{13}$ Enquanto a manutenção do modelo de organização restringia os espaços de negociação de influências exógenas ao evento, que era geralmente sustentado por argumentos de identidade reconhecidos localmente, a manutenção do modelo de programação exteriorizava uma recorrência de manifestações legitimadas pela autenticidade, ${ }^{14}$ amplamente reproduzidas pelos meios de comunicação que cobrem o evento.

Assim, durante muito tempo a festa reproduzia não somente as suas manifestações tradicionais, senão também uma ordem de relações especializadas entre os atores locais, dispostas em uma hierarquia coletivamente estabelecida e legitimada, na qual a negociação constante entre os atores institucionalizados eclesiais e leigos orientava as pautas de ação do projeto de promoção do evento, mesmo que tensionada por conflitos constantes. Na ausência de agenciamentos exógenos desagregadores, as tipicidades características de um mundo pressuposto (Schutz 2003) das manifestações religiosas tornavam recursivas as finalidades definidas pelos agenciamentos endógenos.

Porém, algumas mudanças aconteceram nesses modelos, nas últimas décadas, promovidas ora pela imposição constante de agenciamentos exógenos - na década de 1990, evidenciou-se progressivamente uma exposição midiática de algumas manifestações religiosas e culturais da cidade, como a Festa do Divino, as atividades da Semana Santa e o Carnaval, e desde 2002, quando a cidade é elevada à condição de estância turística, ${ }^{15} \mathrm{O}$ assédio regular de visitantes provocado pela exposição midiática aumentou consideravelmente, impondo a necessidade de incorporar inovações na gestão dessa realidade (Santos 2008) - ora negociadas por padres que se sucederam na paróquia, após o afastamento por idade do antigo monsenhor no cargo, em meados da década de 1990.

13 A festa é organizada por um casal de festeiros escolhido ou indicado pelo pároco local, que convida outras pessoas a se responsabilizarem por elementos parciais da festa, formando uma comissão que, ao final do evento, presta contas ao pároco. A tradição de realização da festa reproduz-se nos seus elementos, apesar de variarem os atores das comissões encarregadas pelos mesmos, a cada ano. Assim, a decoração da festa, sobretudo do andor e do Império do Divino, esteve a cargo de uma professora local durante décadas. Da mesma forma, o cozinheiro responsável pela preparação do afogado, os noveneiros, o maestro que ensaiava o coral que cantava em latim nas missas, as mulheres que organizavam as seções dos anjinhos nas procissões, os responsáveis das irmandades religiosas locais pelos andores de seus santos, o maestro da Corporação Musical São Luiz de Tolosa e formador da banda que acompanha as procissões, além dos mestres dos grupos devocionais convidados a se apresentar na festa, foram invariavelmente os mesmos durante anos. Nesse sentido, a trajetória histórica da festa produziu uma especialização de saberes e fazeres entre alguns atores legitimados, formando eles um núcleo duro da produção dessas manifestações.

14 As concepções locais de autenticidade, partilhadas entre agentes eclesiásticos, do poder público, historiadores e membros de irmandades locais, assentam-se em registros da antiguidade ou fundação da festa (sua origem), enquanto as concepções de identidade são amplamente reconhecidas pela população como registros de ações tradicionais, pela imersão na rede de relações que se forma em torno do evento, durante todo o ano (sua manutenção ou continuidade).

15 Lei Estadual de São Paulo n. ${ }^{\circ} 11.197$, de 5 de julho de 2002. 
Essas últimas, também sentidas em festas de cidades vizinhas no mesmo período (A. Silva 2009), deveram-se à introdução de práticas e representações religiosas influenciadas pelo Movimento da Renovação Carismática, ou pela formação conservadora e reformista de alguns padres, que não se correspondiam ou reconheciam com as tradições religiosas da população local.

Em 2010, a realização da festa anunciava a tensa continuidade desses elementos, até que dois fatos mudaram o curso dos acontecimentos. Primeiro, uma mudança na ordem das relações especializadas dos atores, devido a que alguns sujeitos locais tiveram projetos de Pontos de Cultura ${ }^{16}$ aprovados em editais do Ministério da Cultura (MINC), em 2009 e 2010. O segundo refere-se a uma enchente do rio Paraitinga, que margeia todo o centro histórico da cidade, ocorrida nos primeiros dias de 2010. Nessa "enchente histórica", o rio subiu mais de dez metros acima de seu nível regular, cobrindo quase todo o centro histórico e provocando desabamentos de vários casarões, além da igreja Matriz e da igreja das Mercês (figura 1).

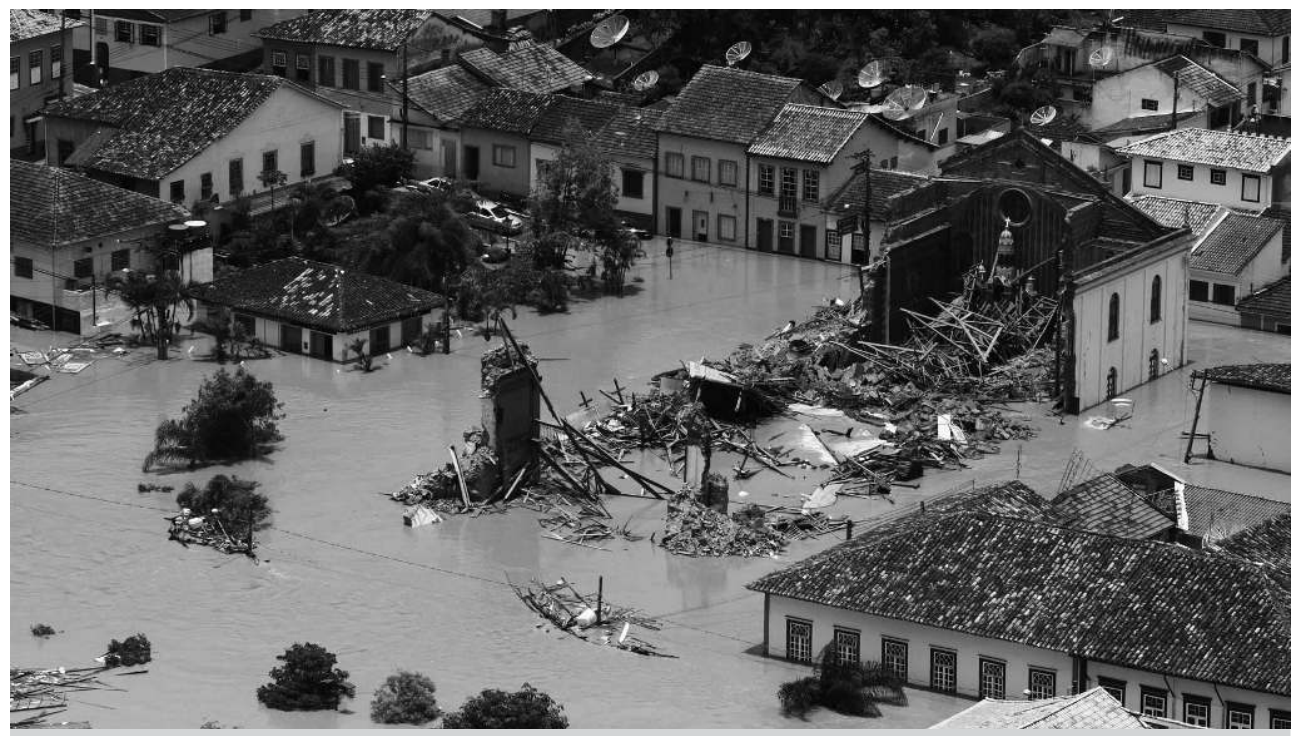

Figura 1 - A igreja Matriz desabando com a enchente.

Fonte: disponível em <http://virgula.uol.com.br/ver/noticia/news/2010/01/03/234310-imagens-mostram-otamanho-da-destruicao-em-sao-luiz-do-paraitinga> (acesso em 20/5/2010).

16 Os Pontos de Cultura são estabelecidos em municípios do país segundo projetos apresentados por atores culturais aos editais do Programa Cultura Viva do Ministério da Cultura. "O Programa Cultura Viva é concebido como uma rede orgânica de criação e gestão cultural, mediado pelos Pontos de Cultura, sua principal ação. A implantação do programa prevê um processo contínuo e dinâmico e seu desenvolvimento é semelhante ao de um organismo vivo, que se articula com atores pré-existentes. Em lugar de determinar (ou impor) ações e condutas locais, o programa estimula a criatividade, potencializando desejos e criando situações de encantamento social" (disponível em $<$ http://www.ipecpesquisas.org.br/usuario/GerenciaNavegacao.php?caderno_id=396\&nivel=3>, acesso em 12/7/2010). 
A enchente, sobretudo, foi um fator importante de mudanças na festa de 2010, porque reforçou elementos do imaginário religioso local relacionados a outros desastres do passado. Assim, era comum ouvir pessoas da cidade estabelecendo comparações desta enchente com outra, "histórica" também, ocorrida em 1863, quando "as águas do rio Paraitinga chegaram até o segundo degrau da igreja Matriz”. Sobre a relação entre este desastre ambiental e o imaginário religioso, Jaime de Almeida escreve:

"É voz corrente que a grande inundação de 1863 ocorreu logo depois que o delegado de polícia prendeu um grupo de folióes do Divino que, sem a devida autorização, esmolava pelas ruas da cidade. O edifício mais importante destruído pela enchente foi justamente a cadeia" (2001: 84).

A catástrofe natural de 2010 teve ampla cobertura jornalística nos meios de comunicação nacionais, gerando uma série surpreendente de manifestações solidárias, que foram de visitações de apoio de personalidades midiáticas até a realização de vários shows ou eventos promovidos por instituições, artistas e jogadores de futebol, visando arrecadar fundos para a reconstrução da cidade ou o atendimento das pessoas e famílias mais atingidas. Durante os primeiros meses após a enchente, era comum ver grupos organizados de denominações religiosas, torcidas organizadas de futebol, instituições filantrópicas, entre outros, visitando a cidade e prestando auxílio na limpeza da mesma, no atendimento de famílias desabrigadas e de crianças, na reorganização do lugar ou na reconstrução de prédios.

Evidentemente, os estragos causados pela enchente ${ }^{17}$ afetaram a autoestima da população, gerando um clima de desconsolo e abandono generalizado, que foi agravado pela demora das intervenções governamentais em prover os recursos necessários para o restabelecimento das relações cotidianas, em condições dignas. Por outro lado, o desabamento dos lugares centrais de realização dos rituais da Festa do Divino, como a igreja Matriz, gerou um debate extensivo na população sobre a plausibilidade de sua realização, nesse ano. Esse é o contexto em que descrevo as manifestações ocorridas no período central da festa.

\section{O DIVINO RETORNO: REGISTROS ETNOGRÁFICOS DE UMA FESTA RENOVADA}

Desde a chegada a São Luiz do Paraitinga no dia 20 de maio, à noite, era perceptível um espírito que tomava conta da cidade. A praça Oswaldo Cruz estava toda decorada com bandeirinhas vermelhas e via-se uma cobertura de lona

17 Outros registros imagéticos dos estragos causados pela enchente podem ser visualizados em sítios diversos na web, através de uma busca na plataforma Google. Conferir, por exemplo, <http://www.oeco. com.br/fotografia/23433-sao-luis-do-paraitinga >. 
armada em frente ao coreto, formando um corredor em direção dos escombros da antiga igreja Matriz. Flâmulas vermelhas com a iconografia do Divino estavam debruçadas nas janelas dos casarões, por todo o centro histórico, como se estivessem comemorando a conquista de ainda estarem de pé, depois da enchente que derrubou vários deles, e a própria igreja.

Entre atividades e sensações que compõem o ambiente da festa, havia muitas pessoas circulando apressadas de um lugar para outro. As do lugar ajustavam os últimos preparativos dos lugares da festa, enquanto as de fora simplesmente circulavam curiosas de ver os estragos que a enchente deixou pelas ruas e casarões.

Reencontramos pessoas conhecidas e os assuntos das conversas que se desenvolveram até tarde da noite tinham dois temas que sempre se alternavam ou complementavam: a reconstrução da cidade, depois da enchente, e a "volta às origens" da Festa do Divino. De tanto ouvir essas referências associadas discursivamente, não havia como deixar de pensar no quanto a memória coletiva é ativada conscientemente em situações de desagregação - imaginária ou real (Halbwachs 1990) -, como a causada pela imensa enchente, no início do ano. ${ }^{18}$

A manhã da véspera da festa, no dia 21 , expõe mais personagens e situações que convergem para a sua organização e se intensificam durante todo o dia. Caminhões e funcionários da prefeitura local circulam pelas ruas, dando os últimos ajustes na infraestrutura do evento, que ganha forma, intensidade e se mostra mais visível. Circulo entre lugares e pessoas que organizam e efetuam a festa, e vou percebendo suas permanências e mudanças, em relação às edições anteriores. Além da já mencionada cobertura armada na praça, que substitui o espaço da igreja Matriz, a interdição da rua que liga a rodoviária ao centro histórico, em função de um deslizamento de terra, leva os organizadores a transferirem o local de distribuição do afogado para o mercado municipal. A última vez que isso aconteceu foi em 1980 e o retorno da atividade ao lugar foi o fator inicial a produzir um clima de retorno às origens.

Complementando esse clima, por todos os cantos da cidade há fotografias expostas com referentes da memória coletiva, em imagens dos casarões derrubados, de festas antigas, de pessoas conhecidas já falecidas, das várias paisagens que a praça já assumiu no passado, além de outras situações.

18 Segundo Halbwachs (1990), a memória reproduz simbolicamente significados partilhados e vivenciados por grupos, comunidades e sociedades, de forma a dotar de sentidos os acontecimentos históricos e permitir a incorporação de conceitos na experiência coletiva. Nesse sentido, memória e imaginação operam regularmente contrações uma sobre a outra, como já indicou Deleuze (1988). Buscando interpretar essas contrações, Santos descreve: "Jean Duvignaud, comentando o texto de Halbwachs, constata, a partir dessa discussão, a distinção entre a 'memória histórica' formada pelos fatos do passado construído a partir do presente, e a 'memória coletiva' que traz um aspecto mais mágico a este mesmo passado. A festa permite a construção dessa memória coletiva e também acaba influenciando diretamente a história do local no qual se realiza" (2008: 17). 
Em meio a essa imagética da memória que se mistura com a "decoração" da festa, a imagem da igreja Matriz é um ícone recorrente. E se hoje a igreja está em escombros, vai se evidenciando nessa imagética da memória a importância que esse espaço possuía, e possui, como referente que projeta um "imaginário coletivamente significante" para a identidade do lugar, um "nós" à maneira meadiana (Mead 1982). ${ }^{19}$

Entre outras referências dessa imagética da memória que gravitam em torno da igreja, o tapume que cerca a obra de reconstrução da mesma foi todo preenchido com desenhos pintados por alunos das escolas do centro da cidade (figura 2). O tema desses desenhos é a própria igreja, de forma que seus escombros estão literalmente cercados de imagens do que ela ainda significa para as pessoas do lugar, em sentidos figurados diversos, que se intercalam horizontalmente com os logotipos do Instituto do Patrimônio Histórico e Artístico Nacional (IPHAN), e da empreiteira Biapó, que assumiu o projeto de reconstrução da igreja.

Outros referentes importantes dessa imagética estão localizados no mercado municipal e no Império. No mercado, uma exposição de fotografias coloridas de Rosa Gauditano, sobre aspectos da Festa do Divino de 1984, plotadas em painéis plásticos, recria o ambiente festivo de "antigamente", também composto pelas bandeirinhas vermelhas distribuídas entre o telhado e uma grande barraca armada no seu interior, para a distribuição do afogado. No Império, um grande quadro com a fotografia da igreja Matriz está exposto no espaço de um altar central, antes ocupado pelo andor do Divino Espírito Santo.

Essa disseminação de uma imagética ${ }^{20}$ que reforça a memória local nos lugares de sociabilidade da festa, enfatizando elementos de tradição, vai

19 E se Mead expõe esse "nós" na forma de um "outro generalizado, ou organizado" (1982: 184), que permite aos self individuais desenvolver um centro de atividades, ou estrutura de atitudes, nas interações sociais, é também verdade que os objetos que formam o ambiente dessas interações podem se assumir, ou serem apropriados, nas identificações dos outros com quem interagimos, assumindo uma centralidade como mediação, em alguns casos, pelo caráter significativo que propiciam à organização das mesmas interações. Esse é o caso da igreja Matriz de São Luiz do Paraitinga, como pude verificar, mesmo antes da festa, em vários depoimentos de sujeitos da cidade entrevistados por emissoras de televisão, logo após a queda da igreja, durante a cobertura que realizaram da enchente.

20 O termo imagética busca imprimir um caráter substantivo ao conjunto de imagens que se entrelaça e gravita em torno de determinadas práticas religiosas e vivências devocionais contemporâneas. Buscando superar a importância secundária atribuída ao uso das imagens no entendimento do fenômeno religioso, tratando-as regularmente como um registro simbólico que se reproduzia desde práticas e estratégias institucionais de evangelização ou difusão doutrinal das denominações religiosas, a concepção de imagética religiosa, ou devocional, requer reconhecer um caráter presencial às imagens, na contemporaneidade, que extrapola a impressão de um registro simbólico produzido fora delas, para, a seguir, interpretar essas presenças como constitutivas de redes de sentido, organizadas em torno de determinadas devoções e práticas religiosas. Assim, as imagens religiosas e devocionais existem como suporte ritual de demarcação social, uma espécie de geografia do sagrado ou, ao menos, das experiências religiosas vivenciadas pelas pessoas em determinadas situações (Lopes 2010). 


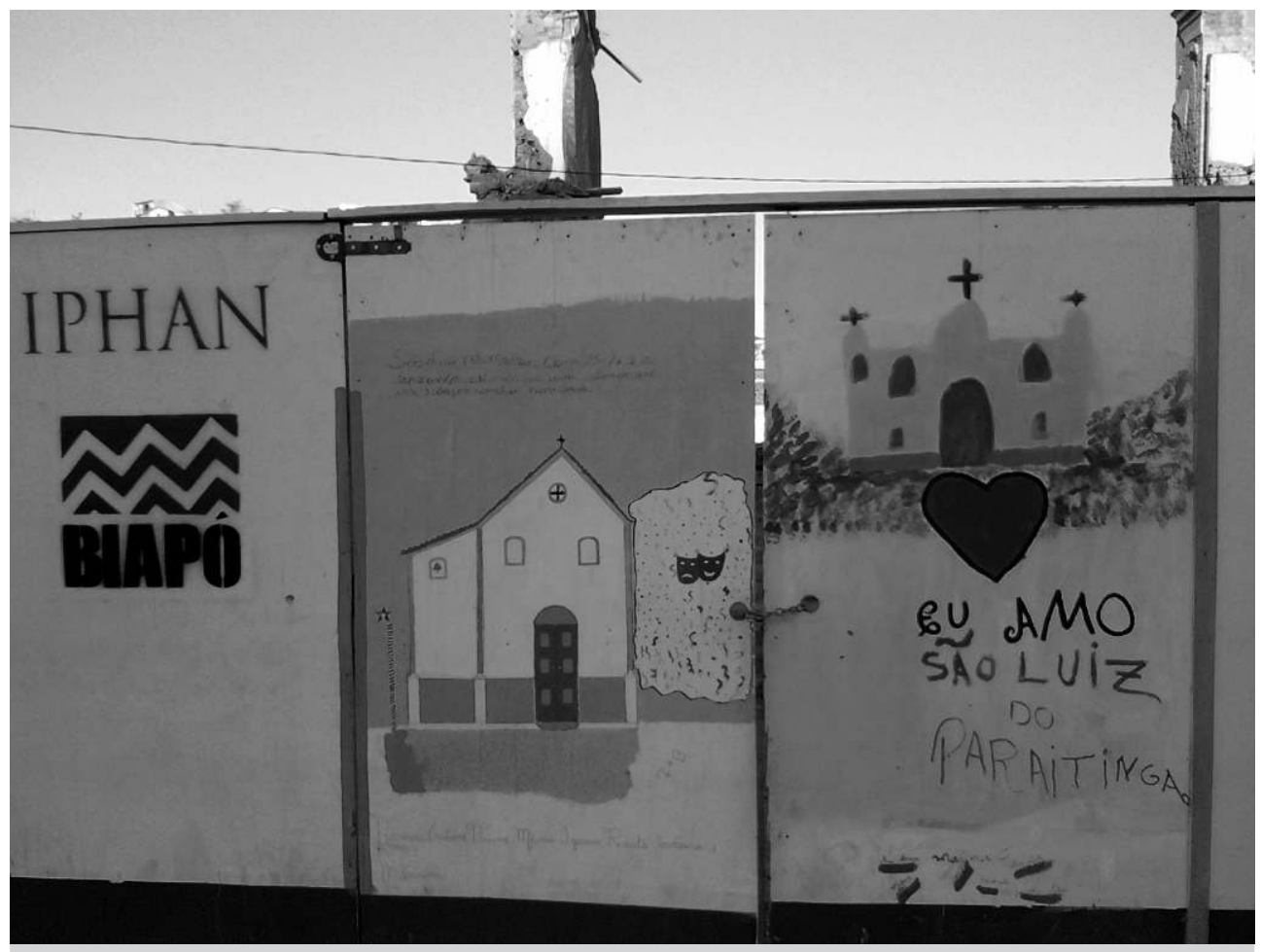

Figura 2 - Desenhos no tapume em torno da igreja Matriz.

Fonte: Arquivo do autor, 2010.

constituindo uma convergência identitária que agencia a religiosidade e a cultura locais. Se tal convergência de elementos festivos, religiosos e culturais era agenciada inconscientemente na organização de festas anteriores, em 2010 ela produz uma síntese original, nesse contexto, como nas missas que encerram os cortejos processionais dos rituais da festa, no sábado e no domingo, quando a liturgia dos cultos é acompanhada por corais e músicos que entoam canções tipicamente "caipiras", ou do cancioneiro popular devocional, como "Os devotos do Divino" ou "Cálice bento". ${ }^{21}$

Durante todo o dia, essas percepções se reforçam nas visitas que fazemos em casas de moradores locais, para realizar entrevistas ou encontrar pessoas

21 As edições anteriores da festa realmente não tinham esse caráter popular expresso na liturgia dos rituais. Até 1988, inclusive, as liturgias das missas de festas do Divino que acompanhei, na cidade, eram todas cantadas em latim, por um coral que se prostrava no mezanino anterior superior da nave da igreja Matriz. Esse elemento ortodoxo do ritual foi substituído pelas liturgias acompanhadas de cânticos evangelizadores de orientação reformista, como se verificou ocorrer nos centros urbanos do país, desde o final da década de 1980, e que predominavam até a festa de 2009, em que pesou a influência ocasional dos carismáticos, que renovaram a liturgia das missas com suas canções em estilo gospel. 
conhecidas. As casas geralmente estão em reformas, propiciando propósitos para conversar sobre a reconstrução da cidade e "da vida", ou são depositárias de materiais e recursos diversos que seriam utilizados na festa, motivando conversas sobre sua organização ou o caráter extraordinário do evento que inverte o cotidiano das pessoas e famílias.

Entre tais visitas, alternamos a orientação do olhar que observa para outras particularidades ainda não percebidas. Isso possibilita encontrar indícios de outras presenças religiosas nessa festa devocional católica, que gravitam em torno dos temas recorrentes ou predominantes na situação pesquisada, ou se apropriam do imaginário coletivo que ali se refaz, pela convergência dos fatores já esboçados. Nesse momento, destacaria três deles. O primeiro se refere a cartazes espalhados em murais da cidade, produzidos pela Igreja Universal do Reino de Deus, onde constava uma evocação provocante, em caixa alta - "Deixa Deus guerrear a sua guerra" -, complementada por considerações textuais sobre a importância de confiar a Deus a resolução da desagregação conflitiva que a sensação de abandono e perda produz na vida coletiva e na autoestima dos indivíduos. Essa evocação era acompanhada de informes sobre locais e horários de cultos, na cidade.

O segundo é um folheto dobrável em três abas, produzido pela Primeira Igreja Batista, da cidade de São José dos Campos, e distribuído pelas casas e lugares públicos. $\mathrm{Na}$ aba da frente se destaca a frase "Deus ama essa cidade, mas ama ainda mais você!" A segunda aba, interna, traz o seguinte enunciado:

"A reconstrução e restauração completa da cidade levará alguns meses, talvez anos. Dependerá de muito dinheiro e trabalho. Porém para dar início na reconstrução de sua vida basta você olhar para Jesus e dizer: sim, eu aceito como meu único Senhor e Salvador. Ele virá com seus braços de amor, o abraçará e iniciará uma grande obra em sua vida."

Muito providencialmente, a terceira aba, externa, trazia a foto de uma janela típica dos casarões da cidade, utilizada recorrentemente em quadros de pintores locais e em produtos artesanais vendidos em lojas locais. Por fim, a aba que fazia o anverso do folheto, quando fechado, trazia convites para assistir "o programa da Igreja na TV Bandeirantes, aos sábados, às 10h", e o site da Igreja na web.

O terceiro é um folheto, também dobrável em três abas, produzido e distribuído pela denominação religiosa Testemunhas de Jeová. Trata-se de um típico folheto de divulgação dessa denominação religiosa, mas selecionado também providencialmente para a situação. $\mathrm{Na}$ aba que abre o folheto, lê-se o título: "A Vida num Pacífico Mundo Novo". Nas abas internas, um longo texto composto de excertos de passagens bíblicas do Gênesis (1:28), do Apocalipse (21:4), dos evangelhos de Pedro (3:13), Isaías (65:17; 55:11; 2:4; 33:24), 
Mateus (6:9), Miquéias (4:4), João (17:3), e dos Salmos (89:36; 37:29; 67:6; 72:16), discorria sobre a razão para ter esperanças em um mundo novo, frente à experiência desagregadora das realidades de hoje.

Dessa forma, outros agenciamentos religiosos efetuados na festa ${ }^{22}$ também articulavam os temas recorrentes da reconstrução (da cidade e "da vida") e da volta às origens, assim como os elementos convergentes em torno da síntese entre festividade, religiosidade e identidade, em contextos de desagregação imaginária e concreta da vida coletiva.

O encontro desses indícios reforçou uma prática de coleta de folhetos distribuídos nesses eventos, que aprendi a considerar desde a experiência de campo na festa do Círio de Nazaré. ${ }^{23}$ E essa prática se mostrou provocativa de novas apreensões em São Luiz do Paraitinga. Assim, quando estava coletando um desses folhetos jogados no chão, fui abordado por um conhecido local, que é promotor público em Taubaté, uma cidade próxima. Indagando-me se eu estava limpando a cidade, começou a expor a possibilidade de realizar outras formas de auxiliar a cidade, em suas necessidades atuais. Ele havia criado, juntamente com outras personalidades locais, uma associação que objetivava auxiliar a reconstrução das casas das pessoas pobres que haviam sido derrubadas pela enchente, e precisavam de doações. Embora já conhecesse a iniciativa, através de matérias de jornais publicados em edições online, impressionou-me a sua disposição para abordar diversos conhecidos durante todo o período da festa, sobretudo porque ele estava se recuperando de um sério acidente de motocicleta que sofreu na estrada de Taubaté para São Luiz do Paraitinga, justamente no período posterior ao da enchente, em que atuou ativamente no cuidado à população mais afetada.

A festa adquiria, com esse e outros agenciamentos similares, um caráter ampliado de evento solidário, ${ }^{24}$ pela negociação entre atores endógenos e exógenos ao lugar, na apropriação de recursos para a reconstrução da cidade.

22 Aqui, exponho um caráter dos agenciamentos religiosos sobre a festa que é decorrente de tentativas de resgatar a autoestima da população local. Entretanto, esses agenciamentos religiosos operam também outras influências sobre a população e a festa, na medida em que configuram lentamente um campo religioso plural na cidade, de concorrência pela apropriação de fiéis, como descrito em Santos (2008: 157-162). Ocorre que essa pluralidade reduzia-se a mais quatro denominações evangélicas e um terreiro de umbanda, com sedes em áreas periféricas da cidade, até o período da enchente. Em 2011, quando retornei à cidade para acompanhar a festa, o secretário de Turismo da prefeitura me informou que haviam se registrado e sediado no município dez novas denominações evangélicas. Algumas, como a Igreja Universal da Graça, ocupavam antigos casarões na região central da cidade.

23 Na festa do Círio de Nazaré, na cidade de Belém, estado do Pará, percebi que esses folhetos eram produzidos e distribuídos pela maioria dos atores que agenciavam algum tipo de recurso identitário no evento, buscando apropriar-se do capital simbólico em difusão nos seus rituais centrais e provocando fluxos que atravessavam a ordem e o controle da linearidade de suas atividades.

24 Aqui, sigo a concepção de Lipovetsky (2000), quando analisa os agenciamentos de recursos realizados por atores envolvidos em eventos de massa, na contemporaneidade. Para esse autor, [continua] 
Porém, um aparente paradoxo se expõe nas situações que compõem esse evento, quando chega o sábado e, desde cedo, forma-se uma fila enorme de pessoas do lugar e de visitantes, nas ruas de acesso ao mercado municipal, para a distribuição do afogado. Na edição da festa desse ano, foram "carneados" 18 bois para a preparação do alimento distribuído à população, em um suposto desperdício de recursos em tempos de escassez, ${ }^{25}$ como me afirmaram alguns sujeitos locais. ${ }^{26}$

Esse paradoxo, entre outros, emerge nas conversas coletivas que presenciei, ou das quais participei, durante o evento. Nessas conversas, a realidade ali produzida era novamente debatida e negociada entre pessoas do lugar e de fora dele, de forma que as "ações latentes e manifestas" (Schutz 2003: 49) na festa religiosa eram medidas em termos valorativos por propósitos definidos em escalas e situações distintas daquelas que formavam tradicionalmente o evento, explicitando agenciamentos de interesses e projetos diversos buscando sobreporem-se uns aos outros.

Nesse período da festa, esses agenciamentos eram perceptíveis em outros círculos de conversação (Simmel 1983). Isso foi o que ocorreu, desde o almoço de sexta-feira, em um restaurante local, de propriedade de Pedro. O diálogo com Pedro evidenciou e reforçou outra mudança na lógica dos atores locais e seus agenciamentos, que extrapolavam o contexto da festa, mas assumiam especificidades manifestas na mesma. Ocorre que alguns atores culturais locais - incluindo o próprio Pedro - tiveram projetos de Pontos de Cultura aprovados

[continuação] a própria ideia de solidariedade se espetaculariza, nesses eventos, em uma expressão pós-moderna da solidariedade orgânica. Aqui, busco enfatizar que os agenciamentos de recursos para a reconstrução da cidade operam com mais força nos eventos festivos da cidade. O Carnaval é outro exemplo. Em 2010, logo após a enchente, ele foi suprimido do calendário local, retornando em 2011 com um novo modelo de organização e programação, e chamado de "Carnaval solidário".

25 Embora a questão da escassez/desperdício tenha sido o motivo das discussões aqui analisadas, é importante reconhecer que a concepção de fartura compõe uma díade complementar com aquela, na distribuição de alimentos tradicional nas Festas do Divino. "Simbolicamente, 'dar de comer' implica em fazer o corpo do outro, dar substância ao visitante. A distribuição alimentar, um gesto de caridade e bênção, é parte fundamental da etiqueta e da ética das festas do Espírito Santo, bem como seu vasto consumo" (Veiga 2008: 140). Ver também a análise sobre as festas do Divino nos Açores elaborada por Leal (1994), sobretudo o capítulo intitulado "Jantares, gastos e festas", em que o autor expõe as redes sociais envolvidas na produção, distribuição e consumo de alimentos.

26 Esse aparente paradoxo também encontra respaldo no imaginário e na memória locais. Jaime de Almeida (2001) relata que foi o desperdício de alimentação que levou, inclusive, o monsenhor da cidade, em 1918, a interromper sua realização: "A festa manteve a tradição dos divertimentos profanos e da comilança até 1916, quando a fartura e o desperdício atingiram um grau inusitado. A casa da festa serviu comida à vontade a toda a população durante oito dias; os 28 degraus do casarão tinham dois dedos de comida pisoteada; 150 leitoas, além das muitas rezes e aves, foram abatidas. Contra tais excessos, o vigário Ignacio Gioia proibiu o sorteio do próximo festeiro e suspendeu alguns divertimentos profanos e a distribuição de comida. Em 1918, já não houve festas profanas [...] A tradição só foi retomada em 1940" (Almeida 2001: 84). Essa questão foi retomada, em 2008, gerando uma discussão acalorada entre o pároco e o prefeito locais, como relata Santos (2008: 163-164). 
nos editais do Ministério da Cultura, em um total de cinco, no município. A implementação desses projetos alocou recursos diretos para esses atores, permitindo uma relativa autonomia de ação dos mesmos, em detrimento do modelo de agenciamento prevalecente no município e no estado de São Paulo, baseado na dependência dos mesmos das definições e diretrizes das políticas culturais dos governos municipais e estadual. Neste modelo, geralmente a liberação de recursos converge para a implementação e manutenção de um calendário cultural oficial do estado, com circuitos identitários elaborados sobre manifestações culturais materiais e imateriais de determinadas regiões. Constituídos no âmbito de planos de governo, esses calendários privilegiam ou priorizam manifestações organizadas segundo critérios oficialmente legitimados de cultura, incluindo-se aí um "campo de possibilidades abertas" (Schutz 2003) às especificidades locais que compõem regiões e estados do país. Ora, os atores culturais que agenciam projetos, nesse modelo, tendem a especializar sua performance segundo os "imperativos sociais de desempenho" (Yúdice 2006) estabelecidos nas trocas e circularidades de influências políticas em jogo, nesse processo reproduzindo normas e modelos circunscritos em um campo hegemônico de legitimações e reconhecimentos. ${ }^{27}$

Os projetos e manifestações dos atores locais, em São Luiz do Paraitinga e durante a Festa do Divino, por outro lado, evidenciam a potencialidade dos Pontos de Cultura implementados no município para mudar a escala hierárquica das relações locais de agenciamento de recursos e romper com a lógica de uma hegemonia no campo cultural. Essa potencialidade se efetua na medida em que os recursos agenciados permitem estender as deliberações da ação dos atores para um "campo de possibilidades problemáticas" que extrapola, por sua vez, o mundo pressuposto da ordem tradicional da cultura.

Todavia, ao extrapolar o mundo pressuposto dessa ordem tradicional, tais atores utilizam algumas tipicidades constituídas e constituintes da cultura local para fabricar novas identidades. Assim, na maioria dos casos observados durante a festa, esses atores e seus projetos efetuam "traduções" (Hall 2005) das manifestações locais, que retroagem nos circuitos e atividades do evento. ${ }^{28}$ Cito dois casos: em um, Cláudia, professora e moradora local, que teve um

27 Desde a noção de agenciamento esboçada por Yúdice, trata-se de identificar atores que agenciam recursos identitários recuperados de uma "reserva disponível" nas trajetórias comuns de suas formações culturais, em diálogo com modelos culturais (no caso, estatais) predominantes na sociedade globalizada. Esse predomínio se expressa na configuração de um campo de forças performativas a condicionar a ação dos atores que, por vezes, imprimem uma dinâmica de operar agenciamentos nos intervalos daqueles modelos.

28 E lembrando Stuart Hall (2005: 103), essas traduções são elaboradas “[...] por gente que viaja, mesmo quando permanece em suas casas ou escritórios”. Nesse sentido, é próprio afirmar que as traduções podem até ser locais, mas os criadores culturais que as elaboram são "sujeitos em trânsito" pelos processos da globalização, como o "homem em trânsito" consumidor de cultura, descrito por Toffler (1965: 50). 
projeto de Ponto de Cultura selecionado nos editais do MINC, utilizou os recursos obtidos para montar o Moçambique São Luiz do Paraitinga, formado predominantemente por mulheres. Como o moçambique de Cláudia é composto por algumas professoras do município, também é conhecido como "moçambique das professoras". Além das mulheres que dançam, o grupo é composto também por três homens: dois instrumentistas (acordeom e caixa) e um mestre, que ordena músicas e performance das demais. O segundo é o caso de Pedro, que utilizou os recursos obtidos para montar a Imperial Congada Cortejo de Todos os Santos, formada por sujeitos predominantemente de fora do lugar, mas que frequentam a cidade regularmente e com ela mantêm alguma relação. Neste caso, são sujeitos ligados à mídia regional, professores de universidades e cursos pré-vestibulares, ou agentes culturais e de ONG, de cidades próximas de São Luiz. O grupo se apresenta com várias mulheres na frente, uniformizadas e carregando grandes bandeiras, bem decoradas, que também desempenham as vozes do coro, nas canções entoadas pelo grupo. Às mulheres, segue um cortejo de instrumentistas, com várias violas e violões, caixas, tambores e pandeiros, com uniformes que mesclam motivos de grupos devocionais com traços carnavalescos.

As formas de inserção desses projetos na festa se efetuaram segundo estratégias distintas. O moçambique "das professoras" se apresentou no sábado e no domingo, no meio de outros grupos populares, disputando espaço e audiência com os mesmos no entorno da praça Oswaldo Cruz, durante os intervalos dos rituais religiosos oficiais da festa. Já a Imperial Congada saiu em horários alternativos - na noite de sábado e no fim da tarde do domingo -, inaugurando um novo circuito de apresentações, que começava no mercado municipal e percorria ruas que circundavam o centro da festa, mas finalizava em frente ao Império, como os grupos populares tradicionalmente fazem.

Dois aspectos importantes desses projetos agenciados na festa merecem ser destacados. Primeiro, o fato de que os coordenadores dos mesmos imprimiram e distribuíram folhetos informativos de suas manifestações, durante a festa. Segundo, que tais folhetos exteriorizam condições e propósitos distintos acerca dos projetos desses atores. Cláudia distribuía um folheto explicativo da formação do grupo - um impresso caseiro - situando seu vínculo com as atividades do Ponto de Cultura e a proposta da formação do grupo, composto por mulheres. Na sequência, uma chamada para mulheres que quisessem compor o grupo afirmava, em uma forte conotação de gênero:

“PONTO DE CULTURA FAZENDA SÃO LUIZ

Associação Mato Dentro

E.M.E.F. "Cassiana dos Santos Moreira"

Parceiros no apoio da Cultura Popular de São Luiz do Paraitinga - SP

Fale com a gente: (12) 97106020 - (12) 91118085

pontodeculturafazendasaoluiz@gmail.com 
Estamos divulgando a Dança do Moçambique como dança da cultura popular caipira, originária da antiga "paulistânia". Inicialmente desenvolvida por jesuítas e, posteriormente, influenciada pela cultura afro. Estimula a atenção, concentração, coordenação motora, reflexo e condicionamento aeróbico requerendo um esforço mediano. Perda de 350 a 450 calorias em Ih. de prática.

Atividade ideal para todas as idades!

CULTURA POPULAR NO DIA A DIA É A CARA DO BRASIL."

Já Pedro e outros participantes da Imperial Congada distribuíam um folheto impresso em uma gráfica na cidade de Taubaté, nas cores branca e vermelha, onde constavam: um texto de sua autoria, letras de músicas cantadas pela congada, algumas imagens ilustrativas de ícones da festa, e endereços eletrônicos e números de celulares dos seus organizadores. Além das produções diferenciadas dos folhetos, que já apontam para condições e propósitos distintos de seus agenciamentos, destacaria o texto de Pedro, que está grafado na folha inicial de seu folheto:

"Muito se perdeu em nossa cidade. Quando lembramos e falamos da trágica enchente um nó na garganta se forma, calando as palavras. Há muito que limpar, restaurar e reconstruir, ainda temos muito trabalho pela frente. Contudo, o que não pode se perder é a vontade de fazer aquilo que gostamos e valorizamos. Tocar e cantar Congada na Festa do Divino é muito gostoso, 'restaura' nossas Almas, nos alimenta de energia para continuarmos lutando para viver uma vida digna e honesta em São Luiz do Paraitinga, que é um bem de 'TODOs'. Que o Divino nos abençoe! CANTE COM A GENTE!”

Aqui, diferentemente dos propósitos manifestos no folheto do moçambique, enfatiza-se os temas recorrentes nas conversações ocorridas na festa reconstrução da cidade e "da vida", volta às origens - em suas imbricações com outras referências de relações locais, identificadas nas expressões "'restaura' nossas almas", "vida digna e honesta em São Luiz do Paraitinga", e "bem de “TODOS'”. Insinuações veladas, como o gato que passa na sombra, que provocaram reações diversas entre as pessoas que receberam e leram o material, como constatei no domingo da festa.

Ainda no sábado, porém, outras situações explicitaram as combinações e arranjos dos temas da festa. A mais importante delas ocorreu na distribuição do afogado, no mercado municipal. Desde as 11 horas, formava-se uma fila que se projetava pelas ruas que levam ao centro histórico, com centenas de pessoas carregando panelas e vasilhames de plástico para acondicionar a comida. O entorno do mercado estava lotado de pessoas da cidade, distribuídas em 
espaços distintos, que observavam a fila, o preparo do afogado e a sua distribuição, como um espetáculo. Essas pessoas se confundiam, nessas situações, com dezenas de fotógrafos, repórteres e alunos de cursos de graduação - de universidades da região, de São Paulo, Campinas e do Rio de Janeiro. Às 12 horas, começou um show de música sertaneja, no palco montado na rua ao lado da saída principal do mercado, cuja amplificação sonora atinge os sujeitos das duas situações anteriores, tornando-os partícipes de uma espetacularização que atinge os sentidos (físicos e simbólicos) da comunhão comunitária e popular característica da distribuição do afogado, em associação com um show de música sertaneja típico das produções populares da indústria cultural. ${ }^{29}$

Essas situações descritas evidenciam e enfatizam um jogo de significações semânticas variadas do que é o "popular", em tais festas. Se antes tais significações estavam separadas em manifestações que ocorriam em locais e tempos distantes, na ordem da festa, hoje elas se sobrepõem e atravessam, não somente em uma "circularidade de influências" típica dos elementos em jogo nesses eventos, como já descrito por Bakthin (1987), mas também em uma "coetaneidade" de experiências, como descrita por Fabian (2006), onde o partilhamento do mesmo tempo entre atores distintos produz objetivações do real. Nesse sentido, o "popular massivo" e o "popular laico" fundem-se em uma mesma "corporeidade festiva" (Csordas 2004).

O restante do sábado é de calmaria e celebrações religiosas oficiais, que cumprem a programação da festa, sobrando, contudo, espaços marginais para a realização do bingo, no calçadão, e para os encontros etílicos de jovens e demais sujeitos, locais e visitantes, que agora se avolumam nas ruas, restaurantes e bares.

O domingo da festa explode em uma alvorada de fogos de artifício, seguida de uma intensidade de manifestações diversas, que se alternam até o fim da tarde. Grupos devocionais populares de congadas, moçambiques e folias de reis, da cidade e de municípios próximos, se apresentam desde as $8 \mathrm{~h}$, em diferentes lugares, ${ }^{30}$ cruzando-se entre conhecidos, amigos e parentes, em uma trama de trocas simbólicas e de reciprocidade de reverências, definidas por critérios reconhecidos de legitimidade entre eles: os mestres de saber, no comando dos grupos, são os mais reconhecidos; os antigos "na dança"; os que participam há anos da festa; os que participam de redes de parentesco, além de outros critérios.

29 Vistos desde os acontecimentos em torno do afogado, pessoas do lugar e pesquisadores/repórteres são categorias distintas de sujeitos em ação. Vistos desde o show sertanejo, são uma mesma categoria de público. Essas distintas percepções sintetizam bem os fluxos dos agenciamentos que operam sobreposições das esferas culturais e religiosas na Festa do Divino.

30 Neste ano, uma organização da cidade de São Paulo estava gravando, no pátio da Escola Coronel Domingues de Castro, cantorias dos grupos que se apresentavam na festa. Segundo informações de Galvão, ator cultural local, tratava-se de um projeto para produzir um DVD sobre cultura popular na Festa do Divino, com verba da Secretaria de Estado da Cultura de São Paulo. 
Os três momentos de interrupção dessas apresentações são os relativos aos cortejos processionais que anunciam as missas que ocorrem nesse dia principal da festa: o cortejo do Divino (10h), a procissão do mastro (12h) e a procissão do Divino Espírito Santo (18h). O primeiro cortejo cumpre um circuito curto de deslocamento, que sai do Império e segue até a praça, onde ocorre a missa; já o segundo, que ocorre logo depois da missa, segue até a igreja do Rosário, onde ocorre a fixação de um mastro com uma bandeira do Divino. Essa procissão é formada pelo núcleo dos cortejos ocorridos na festa: um casal ricamente vestido de rei e rainha do congo, com uma criança à sua frente vestida de príncipe e carregando um pequeno andor do Divino, os festeiros do ano com sua bandeira, os sacerdotes locais e a banda de música da cidade. A procissão do Divino sai da praça e percorre várias ruas da cidade, circundando todo o centro histórico, até retornar à mesma, onde se realiza uma missa e a festa se encerra, oficialmente. Essa é a grande procissão local, na qual se somam ao núcleo dos cortejos o próprio andor do Divino, dezenas de anjinhos, sete crianças carregando cartazes com os dons do Espírito Santo, senhoras e senhores de irmandades religiosas locais (com os respectivos andores de seus santos), dezenas de antigos festeiros com suas respectivas bandeiras, todos os grupos devocionais presentes na festa e boa parte da população local, além de visitantes e turistas. De novidade nesses cortejos, além dos aspectos já destacados anteriormente, ocorreu a incorporação do quadro com a fotografia da igreja Matriz, exposto no Império, como componente intermediário entre os grupos populares e os anjinhos (figura 3).

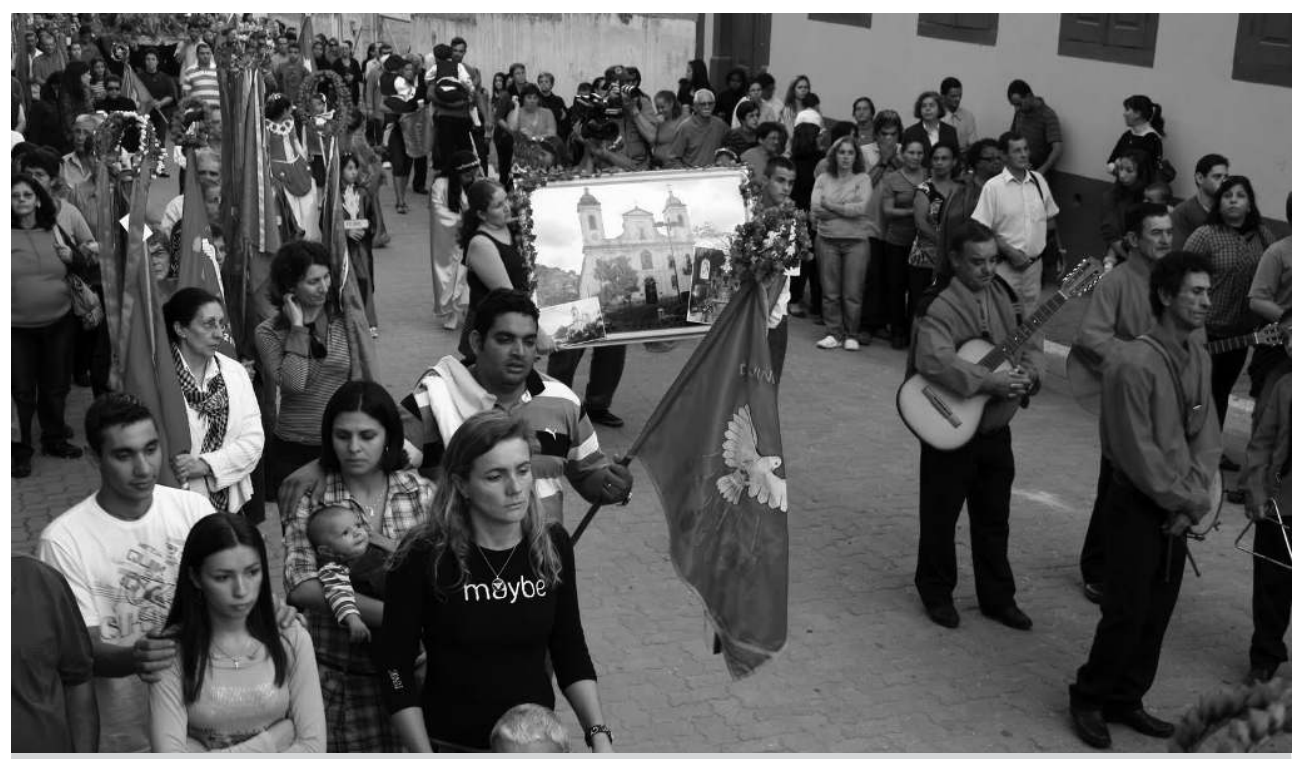

Figura 3 - Quadro da igreja Matriz incorporado à procissão do Divino. Fonte: Rodrigo Manoel Dias da Silva, 2010 (cedida pelo autor). 
O encerramento da missa anunciava um período de finalização da festa, no qual se percebia um gradual esvaziamento das atividades, decorrente da perda de intensidade que se experimentava nesse período. Havia planejado para esse horário um encontro da equipe de pesquisa no restaurante de Pedro, para discutirmos alguns procedimentos posteriores de sistematização do material produzido e coletado durante o evento. Todavia, enquanto me dirigia para lá, com alguns colegas, fomos avisados de uma última manifestação: a apresentação de um grupo de maracatu, que sairia naquele momento do mercado municipal. Chegando ao local, encontramos vários ex-alunos de graduação de Taubaté que compõem o Batuque do Vale, grupo de maracatu formado por iniciativa de dois deles, Itajubá e B.A. O grupo iniciava uma apresentação que seguiria o circuito alternativo inaugurado pela Imperial Congada, no dia anterior, atraindo várias pessoas com seu som acústico de tambores artesanais, cadenciado por chocalhos feitos de cabaça e sementes e tocados por outras jovens do grupo, com uma jovem carregando uma bandeira, à frente. Entre uma música e outra, Itajubá discursava ao público assistente a proposta do grupo, de começar uma nova tradição na Festa do Divino, afirmando que sairiam todo ano, para finalizar o evento.

Após a saída do grupo, sigo para o restaurante de Pedro, pensando que já havia visto tudo da festa. O encerramento dessa experiência etnográfica, porém, foi inusitado.

O restaurante já estava esvaziando, com apenas dois casais jantando perto da entrada, enquanto ao fundo Pedro, um garçom e alguns componentes da Imperial Congada conversavam. Chego com mais cinco colegas e nos sentamos em uma mesa perto dos casais. Durante nossa conversa, Pedro vem se sentar à mesa e trocar ideias. Entre uma cerveja e outra, a esposa de Pedro vem chamá-lo para resolver um problema e ele sai do restaurante. Nesse momento, um sujeito que estava na mesa do fundo, vestindo o uniforme da Congada, se levanta, vai até a porta, olha para fora e volta, dirigindo-se para os que estavam no restaurante em um discurso. Percebia-se que ele estava "alterado", em um estado de nervosismo misturado com embriaguês, enquanto falava em alto tom:

"Esperei o Pedro sair para falar uma coisa para vocês, senão ele me pegava pelo pescoço e colocava para fora. Vocês são uns parasitas! Jornalistas, repórteres, de São José dos Campos, São Paulo, vocês vêm aqui e sugam a cidade, a gente da cidade, mas não deixam nada. Vocês não prestam, bando de hipócritas. O negócio de vocês é se divertir, usar a cidade, e depois vão embora. Hipócritas, sanguessugas. Bando de comospolitas [sic]!"

O sujeito fala e sai do restaurante, deixando uma atmosfera de tremendo incômodo no lugar. $\mathrm{O}$ garçom que estava na mesa ao fundo se levanta e diz para nós: "Liga não, que ele é meio doente, não bate bem da cabeça". De qualquer forma, evidencia-se ali um sentimento de que o discurso do sujeito 
traduz outra lógica de relações entre os elementos endógenos e exógenos que se arranjam ou combinam na Festa do Divino desse ano. E talvez outros discursos e traduções tenham escapado de nossas percepções de pesquisadores.

\section{ENCERRAMENTO PROVISÓRIO}

Diante dessa dinâmica dos fluxos de acontecimentos e manifestações, vem logo à mente a elaboração de Williams (1974) de que os fluxos não possuem sequência. ${ }^{31}$ No caso dessa edição da Festa do Divino de São Luiz do Paraitinga, entretanto, tais fluxos foram produzidos pela ruptura causada por um evento crítico: a enchente. Se o período imediatamente posterior à enchente evidenciou um sentimento de perda e abandono, e uma baixa autoestima coletiva entre a população local, a realização da Festa do Divino buscava uma redenção. $\mathrm{Na}$ medida em que tal evento suprimiu os lugares patrimonializados de referência que davam suporte aos circuitos da festa, impôs também rearranjos nos modelos de sua promoção.

Esses rearranjos organizaram-se de forma diversificada, desde a combinação de registros históricos, como no resgate e exposição de uma imagética do patrimônio local que se confundia com a decoração da festa, até a combinação de registros da memória coletiva, ativados ora pelos agenciamentos religiosos que buscavam resgatar a autoestima da população, ora pelos agenciamentos culturais inovadores dos atores locais. Nesses rearranjos, a imaginação das pessoas projetava imagens dos lugares e representações dos eventos passados, em uma retração sobre a memória coletiva, recriando circuitos que sobrepunham os campos da religião e da cultura, na produção do evento.

De um lado, esses rearranjos resgatavam e atualizavam as redes de solidariedade que sustentam o princípio devocional de realização da Festa do Divino, de outro, introduziam agenciamentos religiosos e culturais que valorizam e atualizam a memória local do patrimônio cultural perdido com a enchente. Assim, tais agenciamentos operados no evento deslocavam seu núcleo hierofânico, descentralizando os elementos que se combinavam na sua configuração, dando ao evento um caráter de ritual complexo. ${ }^{32}$

31 A noção de fluxo está associada à capacidade de estabelecer estranhamentos e foi descrita mais especificamente em Williams (1974), e comentada por sociólogos da cultura como Ramos (1998) e Coelho (1998). Esses autores destacam o impacto causado pelo contato de Williams com a propaganda televisiva, nos EUA, como fator decisivo para a elaboração do conceito de "fluxo", pelo mesmo. $\mathrm{Na}$ contemporaneidade globalizada em que vivemos, esses estranhamentos têm se diversificado, em vez de retraírem, e reforçado uma propensão dos atores sociais a pensarem e utilizarem suas culturas como recurso estratégico de visualização do mundo (Yúdice 2006) ou de gestão de suas relações com alteridades distintas (De Certeau 1994).

32 Aqui, estabeleço uma correspondência com a análise elaborada por Alves (1980) sobre a festa do Círio de Nazaré, na qual a noção de ritual complexo explicita um conjunto de manifestações [continua] 
$\mathrm{Na}$ medida em que os rearranjos agenciados na festa operaram reflexividades sobre seus marcos históricos (que estabeleciam trajetos e movimentações dos atores significativos na produção do evento festivo) e seus circuitos, evidencia-se, aqui, mesmo que pela destruição, que o patrimônio cultural de uma coletividade deve ser pensado em suas profundas imbricações com as relações sociais ou simbólicas desenvolvidas no lugar (ou para além dele), como sugere Gonçalves:

"Afinal, os seres humanos usam seus símbolos sobretudo para agir, e não somente para se comunicar. O patrimônio é usado não apenas para simbolizar, representar ou comunicar: é bom para agir. Essa categoria faz a mediação sensível entre seres humanos e divindades, entre mortos e vivos, entre passado e presente, entre o céu e a terra e entre outras oposições. Não existe apenas para representar ideias e valores abstratos e para ser contemplado. O patrimônio, de certo modo, constrói, forma as pessoas" (2003: 27).

Assim, a desagregação dos circuitos que configuravam a organização e a programação da festa - sustentados por representações tradicionais e complementares de autenticidade e identidade - abriu um campo de possibilidades para rearranjos diversos e complexos, onde os atores endógenos e exógenos à promoção do evento passaram a expressar propósitos manifestos de preservação e mudanças.

$\mathrm{Na}$ diversidade e complexidade desses arranjos se explicita a configuração de vários bens religiosos e culturais, de fundo identitário, e os sentidos das apropriações que devotos e outros atores religiosos e culturais operam desse bem, como demarcação social (Douglas e Isherwood 2006). Tal complexidade, ao expor sentidos de apropriação e demarcação social que os atores operam, também permite pensar que a festa torna-se o ápice de um conjunto de "interações sociais multidirecionais" (R. Almeida 2010: 381) que para ela convergem, no período devocional.

Uma vez que os agenciamentos identitários sempre carregam a marca da ambiguidade, o problema que se coloca aqui é o de perceber a liberdade que os atores exercem de exteriorizar e manifestar essa ambiguidade. A diversidade de manifestações que se inscrevem na Festa do Divino projeta-se como tensão interna dos processos identitários que produzem o evento, em seu conjunto, mas também como agenciamentos dos atores, nos circuitos que efetivam os

[continuação] rituais que gravitam em torno de uma estrutura mítica, ou devocional, de caráter ora residual, ora emergente em relação à centralidade dos eventos que condicionam o curso dos acontecimentos ritualizados. Numa análise correspondente sobre a Festa do Divino em Pirenópolis, estado de Goiás, Veiga (2008: 136) reconhece esse conjunto ao expressar que se promovem "festas dentro da festa". Elaborada sobre a concepção de liminaridade de Turner (1974), a análise de Alves mostra que a oscilação constante do caráter dessas manifestações projeta no evento uma tensão constante entre elementos ou fatores de manutenção e inovação. 
fluxos centrais e secundários da festa. Passa a ocorrer aqui, como em outras festas religiosas que se reproduzem contemporaneamente (Lopes 2011), uma tensão reguladora e constante das próprias relações em que os sujeitos religiosos se constituem, na dinâmica entre interioridade e exterioridade de sua fé.

O reconhecimento das múltiplas manifestações que compõem as festas religiosas faz emergir identidades residuais ou instituintes que demarcam campos internos e territórios de tensão ritual expressivos, que produzem negociações do caráter tradicional da festa com os registros da alma do lugar (Yázigi 2001), em constante processo de mudança. ${ }^{33}$ No caso da Festa do Divino, em São Luiz do Paraitinga, essa emergência também impulsiona a difusão do evento para o encontro com a memória do lugar (Agier 2001) e a própria reconstrução da cidade, em escalas variadas de negociação da diversidade identitária. Assim, essas festas religiosas contemporâneas têm ultrapassado a dinâmica tensa entre as relações estruturais e antiestruturais que configuravam seus rituais, à maneira de Turner (1974), uma vez que a tensão atualizadora dos agenciamentos endógenos aos circuitos e fluxos das festas equilibraria as liminaridades potencialmente disruptoras dos seus circuitos e fluxos exógenos.

Por fim, o que o evento crítico da enchente explicitou, em relação à Festa do Divino, é que ela se rearranja processualmente por agenciamentos diversos, em caminho de uma atualização. Embora o caráter religioso e devocional da festa seja central para a definição e reprodução dos circuitos que compõem o evento, uma vez que ele orienta a atualização da festa como uma "formação inclusiva" (Williams 1979), cada vez mais a festa evidencia-se como um campo dialético que tensiona políticas identitárias, conforme com a análise de Csordas, segundo a qual se deve

“[...] distinguir de forma mais clara entre uma política pessoal de identidade coletiva, na qual atores individuais com compromissos claros lutam para afirmar uma identidade compartilhada, e uma política coletiva de identidade pessoal, na qual cada ator em um grupo de atores com compromissos ambíguos luta para obter uma identidade individual" (2008: 22).

Dessa forma, a complexidade dos agenciamentos operados na Festa do Divino, desde 2010, pode ser definida como uma hipérbole da tensão interna entre os atores e as manifestações que a compõem.

33 "Alma do lugar" é um termo cunhado por Yázigi (2001: 29) para definir a perspectiva do lugar como uma arrumação que produz algo singular, considerado na extensão de seus sistemas. Seu estudo busca afirmar a produção da "singularidade dos lugares", como preservação da paisagem, a partir da contribuição da fisionomia geográfica local para a construção de uma personalidade: "Reconheço o lugar como uma arrumação que produz o singular, mas estimo que de modo algum se poderá entendê-lo ou trabalhá-lo sem a consideração da extensão de seus sistemas. Ele tem uma personalidade sim, mas não é sujeito" (Yázigi 2001: 38). 


\section{BIBLIOGRAFIA}

ABReU, Martha, 1999, O Império do Divino: Festas Religiosas e Cultura Popular no Rio de Janeiro, 1830-1900. Rio de Janeiro, Nova Fronteira

AGIER, Michel, 2001, "Distúrbios identitários em tempos de globalização", Mana, 7 (2): 7-33.

ALMEIDA, Jaime de, 1987, Foliões: Festas em São Luís de Paraitinga na Passagem do Século (1888-1918). São Paulo, Universidade de São Paulo, tese de doutorado em História, 2 volumes.

—, 2001, "As festas religiosas como objeto da História", em Sérgio R. Coutinho (org.), Religiosidades, Misticismo e História no Brasil Central. Brasília, Universa/Cehila, 81-92.

ALMEIDA, Ronaldo de, 2010, "Religião em trânsito", em Carlos B. Martins e Luiz F.D. Duarte (orgs.), Horizonte das Ciências Sociais no Brasil: Antropologia. São Paulo, Anpocs, 367-405.

ALveS, Isidoro M.S., 1980, O Carnaval Devoto: Um Estudo sobre a Festa de Nazaré, em Belém. Petrópolis, Vozes.

BAKTHIN, Mikhail, 1987, A Cultura Popular na Idade Média e no Renascimento: O Contexto de François Rabelais. São Paulo e Brasília, Hucitec e Ed. UNB.

BRANDÃO, Carlos Rodrigues, 1978, O Divino, o Santo e a Senhora. Rio de Janeiro, MEC/ /Funarte.

__, 1981, Sacerdotes de Viola: Rituais Religiosos do Catolicismo Popular em São Paulo e Minas Gerais. Petrópolis, Vozes.

—_, 1983, Os Caipiras de São Paulo. São Paulo, Brasiliense.

— edição.

—_, 1995, A Partilha da Vida. Taubaté, SP, Cabral.

CARVAlHO, Maria Michol P., 2008, "Divino Espírito (re)ligando Portugal e Brasil no imaginário religioso popular”, comunicação apresentada ao VI Congresso Português de Sociologia: Mundos Sociais, Saberes e Práticas, Lisboa, Universidade Nova de Lisboa, 25-28 de junho.

COELHO, Maria Lúcia Bueno, 1998, “Artes plásticas, fluxo visual globalizado e mudanças na percepção", em Alberto da Silva Moreira (org.), Sociedade Global, Cultura e Religião. Petrópolis, Vozes; São Paulo, USC, 27-46.

CSORDAS, Thomas, 2004, "Asymptote of the ineffable: embodiment, alterity, and the theory of religion”, Current Anthropology, 45 (2): 163-185.

— - 2008, Corpo/Significado/Cura. Porto Alegre, Editora da UFRGS.

DE CerteaU, Michel, 1994, A Invenção do Cotidiano, I: Artes de Fazer. Petrópolis, Vozes.

DELEUZE, Gilles, 1988, Diferença e Repetição. Rio de Janeiro, Graal.

DOUGlas, Mary, e Baron ISHERWOOD, 2006, O Mundo dos Bens: Para Uma Antropologia do Consumo. Rio de Janeiro, Ed. UFRJ.

FABIAN, Johannes, 2006, "A prática etnográfica como compartilhamento do tempo e como objetivação”, Mana, 12 (2): 503-520.

FERRETTI, S.F., 2007, “Sincretismo e religião na festa do Divino”, Anthropologicas, 18 (2): $105-122$.

GONÇALVES, José Reginaldo S., 2002, "A fome e o paladar: uma perspectiva antropológica”, em Seminário Alimentação e Cultura. Rio de Janeiro, Funarte/CNFCP, 7-16, série Encontros e Estudos, 4. 
GONÇALVES, José Reginaldo S., 2003, "O patrimônio como categoria de pensamento", em Regina Abreu e Mário Chagas (orgs.), Memória e Patrimônio: Ensaios Contemporâneos. Rio de Janeiro, DP\&A, 21-29.

HALBWACHS, Maurice, 1990, A Memória Coletiva. São Paulo, Vértice.

HALl, Stuart, 2005, A Identidade Cultural na Pós-Modernidade. Rio de Janeiro, DP\&A, $10 .{ }^{\text {a }}$ edição.

HOORNAERT, Eduardo, 1983, "A cristandade durante a primeira época colonial", em E. Hoornaert, R. Azzi, K. V.D. Grijp e B. Brod, História da Igreja no Brasil: Ensaio de Interpretação a Partir do Povo, tomo II/I. São Paulo, Paulinas; Petrópolis, Vozes, 245-41 1, 3. ${ }^{\mathrm{a}}$ edição.

JURKEVICS, Vera Irene, 2005, "Festas religiosas: a materialidade da fé”, História: Questões \& Debates, 43: 73-86.

LEAL, João, 1994, As Festas do Espírito Santo nos Açores: Um Estudo de Antropologia Social. Lisboa, Dom Quixote.

LIPOVESTSKY, Gilles, 2000, El Crepúsculo del Deber: La Ética Indolora de los Nuevos Tiempos Democráticos. Barcelona, Anagrama, 5. ${ }^{\mathrm{a}}$ edição.

LOPES, José Rogério, 2010, A Imagética da Devoção: A Iconografia Popular como Mediação entre a Consciência da Realidade e o Ethos Religioso. Porto Alegre, Ed. UFRGS.

—, 2011 , "Círio de Nazaré: agenciamentos, conflitos e negociação da identidade amazônica”, Religião e Sociedade, 31 (1): 155-181.

MEAD, George Herbert, 1982, Espíritu, Persona e Sociedad, desde el Punto de Vista del Conductismo Social. Buenos Aires, Paidós.

PEIXOTO, Clarrisa N., e Helena I.C.S. NETO, 2006, "Manifestação da religiosidade católica luso-açoriana: a festa do Divino Espírito Santo em Laguna (SC) como veículo de comunicação popular", comunicação apresentada ao congresso Intercom Sul, Unisul Universidade do Sul de Santa Catarina, 4-6 de maio.

PEREZ, Léa F., 2000, "Breves notas e reflexões sobre a religiosidade brasileira", em Léa F. Perez et al., Brasil 500 Anos. Belo Horizonte, Imprensa Oficial dos Poderes do Estado, 40-58.

RAMOS, José Mário O., 1998, "Publicidade global e hábitos de consumo", em Alberto da Silva Moreira (org.), Sociedade Global, Cultura e Religião. Petrópolis, Vozes; São Paulo, USC, 47-55. SANTOS, João Rafael C. C., 2008, A Festa do Divino de São Luiz do Paraitinga: O Desafio da Cultura Popular na Contemporaneidade. São Paulo, Universidade de São Paulo, dissertação de mestrado em História Social.

SCHUTZ, Alfred, 2003, El Problema de la Realidad Social. Buenos Aires, Amorrortu Editores. SILVA, Adriana Oliveira, 2009, A Folia do Divino: Experiência e Devoção em São Luís do Paraitinga e Lagoinha. São Paulo, Universidade de São Paulo, dissertação de mestrado em Antropologia Social.

SILVA, Mônica Martins da, 2000, A Festa do Divino: Romanização, Patrimônio e Tradição em Pirenópolis (1890-1988). Goiânia, Universidade Federal de Goiás, dissertação de mestrado em História das Sociedades Agrárias.

SIMMEL, Georg, 1983, "Círculos sociais", em Evaristo Moraes Filho (org.), Simmel: Sociologia. São Paulo, Ática, 150-164.

TOFFLER, Alvin, 1965, O Povo e a Cultura. Rio de Janeiro, Lidador.

TOLEDO, Marcelo H. Santos, 2001, Espaços Individuais e Coletivos de Sacralidade nos Meios Populares: Um Estudo sobre Imagética, Conflitos Simbólicos e Campo Religioso. São Paulo, Pontifícia Universidade Católica, dissertação de mestrado em Ciências da Religião. 
TURNER, Victor, 1974, O Processo Ritual: Estrutura e Anti-Estrutura. Petrópolis, Vozes.

VEIGA, Felipe B., 2008, "Os gostos do Divino: análise do código alimentar da festa do

Espírito Santo em Pirenópolis, Goiás”, Candelária: Revista do Instituto de Humanidades, 5: 135-150.

WILliAMS, Raymond, 1974, Television: Technology and Cultural Form. Londres, Fontana.

_- 1979, Marxismo e Literatura. Rio de Janeiro, Zahar.

YÁZIGI, Eduardo, 2001, A Alma do Lugar: Turismo, Planejamento e Cotidiano. São Paulo, Contexto.

YÚDICE, George, 2006, A Conveniência da Cultura: Os Usos da Cultura na Era Global. Belo Horizonte, Ed. UFMG. 